Универзитет у Приштини са привременим седиштем (497.11 Пожаревац) у Косовској Митровици https://doi.org/10.46630/ish.6.2020.9 Филозофски факултет ${ }^{2}$ Катедра за српски језик и књижевност

\title{
ТОПОНИМИЈА СРПСКОГ СЕЛА СМОЉИНЦА И ВЛАШКОГ СЕЛА КОБИЉА У ЈУЖНОМ СТИГУ КОД ПОЖАРЕВЦА
}

\begin{abstract}
Предмет нашег интересовања у овом раду јесте топономастика једног дела Браничевског округа, односно топонимија два села која географски припадају области јужни Стиг код Пожаревца. Анализирана су два рурална насеља на крајњем истоку Србије, на граници Србије и Румуније, у међуречју Млаве и Пека. За писње овог рада одабрали смо само два села. Прво проучавано село Смољинац насељено је становништвом српске националности, а у другом селу Кобиљу живи становништво влашког порекла. Оба проучавана насеља налазе се на равничастом терену. Међутим, благих узвишења има и у Кобиљу (обронци хомољских пламнина) и у Смољинцу. Па и поред тога регистрована је релативно богата топонимија, просечно по стотинак топонима у сваком насељу. Урађена је семантичка и творбена анализа пописаних топонима, њихова класификација и регистар пописаних онима.
\end{abstract}

Кључне речи: јужни Стиг, Хомоље, Смољинац, Кобиље, топонимија, регистар топонима.

Крајем 2016. године почео сам са прикупљањем ономастичке грађе у јужном Стигу по селима која административно и катастарски припадају општини Мало Црниће у Браничевској области.

Стиг је једна од највећих равница у Србији. Налази се на простору између реке Млаве на западу и Дунава на северним и источним странама ове области. Са југа и југоистока окружен је обронцима хомољских планина а са истока и обронцима планине Кучај. Северни делови ове области припадају пожаревачкој општини, а на простору јужног стига формирана је општина Мало Црниће са седиштем и средиштем у истоименом насељу.

У литератури нема много грађе ни података о овом крају. Ипак, истраживачи који су се бавили проучавањем Стига истичу да се ради о јединственој

\footnotetext{
${ }^{1}$ jasovicgolub@gmail.com

${ }^{2}$ Рад је написан у оквиру пројекта „Дијалектолошка истраживања српског језичког простора” 178020 , руководилац проф. др Слободан Реметић, који се реализује уз помоћ Министарства за просвету, науку и технолошки развој Републике Србије.
} 
антропогеографској територији и да се због низа својих специфичности може сматрати посебном културном цлином (Младеновић и Јацановић, 2002: 157).

О пореклу имена Стиг постоји више предања и легенди. Будући да ce ради о терену који раван и испресецан бројним рекама, речицама и потоцима,неминовно је од вајкада постојање бара и језераца. На таквом влажном и мочварном терену расли су пространи тршчари. А у тим мочварама уточиште су налазиле немани и чудовишта која су често доносила невољу становницима ових крајева. По једном предању у тим мочварама је живела аждаја која је наносила зло локалном становништву. Да би се решили аждаје људи су једне године спалилио трску (наводно то је урадио деспот Ђурађ Бранковић Смедеревац), а аждаја је побегла преко данашњег брда Бегановца, у атару села Кула, а Ђурђе ју је стигао у Стигу и одсекао јој главу.

Међутим, име ове области нема никакве везе са глаголима стићи и стизати. Пре ће бити да је у његовој основи грчки облик стигео, стигнос/cmuгос, што на грчком језику значи мрзак, ужасан, мрачан, таман, црн, проклет, тужан. Од исте основе је изведено и име реке Стикс (у генитиву Стигос), се налази у подземном свету, а којом Харон чамцем превози душе покојника (Младеновић и Јацановић, 2002: 157).

Област читавог Браничева и Стига у у њему је месту на којему је било добрих услова за насељавање и живот људи. Недалеко одавде су и откривене прве људске насеобине у овом делу Европе на српској дунавској долинској страни у Лепенском Виру.

За писање овог рада одабрана су два јужностишка села. Село Смољинац насељено српским становништвом православне вере и село Кобиље у којем живи становништво влашког порекла, такође, православне вероисповести. И у једном и у другом селу, према казивањима наших информатора, данашњи становници живе више од два века. ${ }^{3}$

Село Смољи́нац је удаљено седам километара североисточно од Малог Црнића. Од раскрснице на путу Пожаревац-Кучево удаљено је 3-4 километра. Некада је имало 850 кућа, а сада има око 550 кућа и 2500 становника. Смољинац је делимично урбанизовано насеље збијеног типа. Има свој центар и куће изграђене дуж неколико главних улица испреплетаних уздуж и попреко по насељу образујући тако један овећи круг.

Граничи се са селима: Шапине, Забрега, Дољашница, Велико Црниће, Мало Градиште, Салаковац, Сираково, Љубиње, Касидол, Баре, Братинац и Набрђе.

Становници села претежно се баве ратарством и сточарством. Било је познато по производњи опеке и бибер црепа. Данас се баве савременим занатима, трговином и услужним делатностима.

\footnotetext{
${ }^{3}$ Већина становника села Смољинца су досељеници из Старе Србије, са простора данашњег Косова и Метохије, околине Врања и Бујановца, али и из околине Куманова и скопске Црне горе.
} 
Помиње се у Раваничкој повељи кнеза Лазара из 1380. године. У деветнаестом веку Смољинац је највеће насеље у Стигу. Имало је тада више дућана од Пожаревца. Године 1991. село је имало 637 домова и 2058 становника, а 2002. године 627 кућа и 1842 становника. Године 2018. пописали смо 490 породица у којима живи 1500 становника.

У селу је 1843. направљена црква посвећена Светим Петозарним мученицима. На крају сеоског атара, на међи са суседним Малим Градиштем налази се црквица Света Петка на приватном земљишту Глише Савића Булчетовог и Сава Љубе Богдановог. Поред цркве постоји извор са лековитом водом. Црква је обновљена 1987. Село има два гробља, Горње гробље, на крају села, на брду према суседном селу Малом Градишту и друго, Доње гробље, на почетку села, према Шапини. Смољинчани славе заветине Велику Госпојину и четвртак пред Спасовдан. На Крстовдан се сваке године у селу одржава сеоски вашар.

Село има осмогодишњу Основну школу „Дража Марковић Рођа“, отворену још на самом почетку деветнаестог века, која има своја истурена одељења у селима Мало Градиште и Шапине.

Становници села су својим прецима страдалим у прошлим ратовима подигли спомен обележја. Једно, борцима страдалим у Првом светском рату 1918. у порти сеоске цркве. Друго обележје подигнуто је борцима страдалим у Другом светском рату, а направљен је и споменик Слађану Стојићевићу који је погинуо у околини Книна деведесетих година прошлог века.

Етници: Смољииччанин, Смољиิнчанка. Ктетик: смољина̋чки.

Село Кобиљье повезано је са магистралним путем Пожаревац - Кучево, а преко Куле и Батуше са Малим Црнићем од којег је удаљено тринаест километара. Граничи се са Аљудовом, Манастирицом, Мустапићем, Малом Бресницом, Макцем, Божевцем и Кулом. Село је брдског типа, а мештани се углавном баве ратарством и сточарстом. У потезу Строш извире истоимени поток који се спаја са потоком Товарија. Оба потока се уливају у Витовницу.

Село је добило електричну струју 1954. године. Први пут се помиње у Повељи кнеза Лазара 1382. и у Браничевском тефтеру из 1467. године када има 19 кућа. Године 1844. помиње се село Кобиље у окружју пожаревачком, срез млавски са 125 кућа и 843 душе. Данас село има 243 куће и око 800 становника. Насељено је влашким живљем. Пореклом су из Звижда, Пореча и из Аустрије (Аустроугарске). Велики број породица напустио је село и иселио се у земље западне Европе, највише у Аустрију, затим у Швајцарску, Немачку и Италију, а један део становника иселио се у оближње градове: Пожаревац, Кучево или Петровац.

Кобиље има цркву посвећену Светом Илији чија је градња почела 1911, а храм је завршен 1927. На Светог Илију је у селу сабор, а заветина је на Спасовдан. У дворишту цркве постоји запис - липа. У Царини је такође било дрво запис, крушка, у Дугарници запис је храст, а у потезу Перииш запис је била, такође, крушка поред које су ђаци држали молитве. 
У делу села Петриิш налази се гробље, а Старо гробље је близу кућа Павловића и Јенића. Неки сељани сахрањени су ван гробља, као Миливоје Дражиловић у потезу Ступин на свом имању, Димитрије Благојевић код свог салаша у Јерници, а Миливоје Мијајловић у месту Старичина.

У селу је прва школа отворена још 1865. године. Дом културе су добили 1953. године, а следеће 1954. године и електричну струју.

У Јерници/Ерници и Старичини је налазиште где су пронађени предмети из римског времена. Постојало је и Јернйчко гробље. Старичина, Товарија и Јерница су формирале Кобиље. Мештани наводе да је село добило име по Милошу Кобиљићу чији коњ је овде сломио ногу. Неки други говоре да су власници сеоске земље биле четири спахије које су имале своју земљу у Старичини, Ерници, Селишту и у Товарији. Спахије из Товарије и из Ернице су се закрвиле, па је као слабији спахија из Товарије натоварио на своју кобилу сав иметак који је могао понети и кренуо према Градишту, али му од претоварености крај једне воде цркне кобила и то место од тада носи име Кобиље.

Етници: Кобйљчаенин, Кобйљчаิнка; ктетик: кобиюљски

Говор становника обрађених села као и читавог Стига јесте косовскоресавски. Чува се троакценатски систем са два стара, новим дугоузлазним акцентом и постакценатским дужинама. ${ }^{4}$

Без обзира на то што је атар оба проучавана села равничаст записана је релативно богата топономастичка грађа. У српском селу Смољинцу чији је атар безмало двоструко пространији пописано је нешто више онима ове врсте (120 топонима), а у влашком селу Кобиљу (84 назива). У оба села укупно су регистровина 204 топонима. У оба пункта преовладавају једночлани називи (у Смољинцу 68, а у Кобиљу 35 ), укупно 103 једночлана назива. У Смољинцу је забележено 47, а у Кобиљу 40 двочланих назива, укупно 87 примера. У нашој грађи налази се и 12 трочланих онима (3 у Смољинцу и 9 у Кобиљу) и само два четворочлана топонима забележена у селу Смољинцу.

\section{І. Класификација микротопонима апелативног порекла}

a) Ороними

БРДО: Виноградско брдо, Огашу вињилор (К); ${ }^{5}$ Голо брдо, виногради, њиве и шума на брду према Малом Градишту; Забрђе, потез, њиве, ливаде, воћњаци, а има и неколико кућа. Налази се северно од села према Божевцу

\footnotetext{
4 Дисперзија акцената може се видети на топонимији објављеној у Регистру назива објављених у овом раду.

${ }_{5}^{5}$ Уместо пуних имена проучаваних села користили смо се скраћеницама (C) за Смољинац и (К) за Кобиље за означавање имена пункта у ком је пример регистрован.
} 
и Макцу (К); Жуто брдо, потез у центру села иза школе и цркве. На том месту постоје остаци неког старог гробља; Старо брдо, виногради на брду према Малом Градишту (C); ВРТАЧА: Вртаче, њиве и шума према Малом Градишту (С); ДОЛИНА: Ваља Николоњ, долина у којој се налазе имања породице Николајевић (К); ${ }^{6}$ Вукин до, шума (С); Куси до, њиве (С); Долови, њиве у удолини више села (С); Мељачка долина, мочварно, мељаво/муљевито земљиште на ушћу Мељачког потока у Витовницу (К); Прода, њиве и пашњаци (C); Содо, обрадива земља, можда је назив настао од синтагме Суви до (С); ДУБРАВА: Дубравиш 'а, обрадива земља (К); Дубрар, обрадиво поље (К); ОБЛЕЖ: Облеж, обрадива земља на брду више села; Велики Облеж, део потеза Облеж; Мали Облеж, в. Облеж (К). ПАДИНА: Падалиште, њиве (С); Падин, обрадива земља (К); ПОД: Подин, њиве (К); СРЕД-: Средица, њиве код Шарене воде на Змајевом брду; ЧАИР: Чаир над село, воћњак, башта (С); ЧУКУР: Чукур, утрина на којој је копана земља за производњу бибер црепа. Ту се налазе јаме дубоке више од три метра (C). ${ }^{8}$

б) Хидроними

БАРА: Баре, њиве и ливаде (С,К); Буруга, бујични поток који отиче са брда Гај и тече према селу Набрђу и улива се у Млаву (С); БУНАР: Код Рофоња бунар, стари бунар у центру села (К); ВОДА: Беле воде, њиве и шума. Поточић који отиче од извора Стублина (C); Водище, потез и кладенац. На овом месту налази се археолошко налазиште из времена Римљана (К); Стошине воде, извор у шуми (С). Стриине воде, шума (С); Шарена вода, извор њиве и ливаде на Дивану (С); ИЗВОР: Велики извор, налази се на крају села у Старичини (К); Драгомировића извор, в. Бишоњ (К); Извор код Свете Петке, извор са лековитом водом код цркве Света Петка (С); Извор у Раниковиу, извор (C); ЈАЗ: Јазови, ливаде на крају села према Малом Градишту, источно од Змајевца. Чува се предање да су то били јазови Берјанаца који су исељавањем из Кућишта у Смољинац основали село. На том месту се налази Берјанско гробље (С); ЈЕЗЕРО: Лак, сеоска утрина на којој се некада налазило језерце (К); ${ }^{9}$ КЛАДЕНАЦ: Ајдучки кладенаи, извор код потеза Дубоки поток (C); Бабин кладенаи, ливаде и њиве на потезу Доња река (C); Влајин кладенаи, ливаде и извор према Малом Градишту (C); Павлов кладенаи, ливаде источно од села (C); ПОТОК: Бели поток, поток, тече са Жутог брда према селу Трњану и улива се у Млаву (C); Водиики поток, изворишни крак потока Строш; Дубоки поток, ливаде и извор. Поток који

\footnotetext{
${ }^{6}$ Ваља на влашком језику долина/до.

${ }^{7}$ Једна ливада у Смољинцу зове се Островац.

8 У Клаићевом Великом рјечнику страних ријечи помиње се секундарно значење ове лексеме: јама, јарак, ров, опкоп, јаруга; шупљина, дупља,; рупа, удубина; прокоп; гроб, рака, гробница; долина, дол (Клаић1968, стр. 236)

${ }^{9}$ На влашком језику лак је језеро.
} 
тече од Гаја према Забреги (C); Дугарнички поток, један од изворишних кракова потока Строш (К); Јернички поток, поток који настаје од два мања поточића који теку од места Касишта и Шерета и уливају се у Товарију, која је лева притока Витовнице (К); Леличин поток, поток на крају сеоског атара према суседном Божевцу (К); Марин поток, потез и поток који се улива у Мељачки поток (К); Мељачки поток, тече крајем сеоског атара, западно од села, паралелно са сеоским међама са Кулом и Божевцем. Настаје од извора Студенац на јужним падинама Дивана и десна је притока Витовнице (K); Поток од чесме, бујични поточић који отиче од чесме кроз центар села и улива се у Строш код сеоског гробља (К); Старичински поток, једна од саставница потока Строш (К); Царински поток, в. Старичински поток (К); ЧЕСМА: Чесма на Жуто брдо, на том месту је страдала ћерка Стевке Бопине, па је ту направљена чесма (C); Стеванова чесма, чесма коју је породица Милошевић подигла Стевану и Живки (C).

в) Називи према величини, облику, саставу и квалитету земљишта

ВЕЛИК: Велики Диван, обрадива земља (К); Велики Облеж, обрадива земља (К); ГО: Голо брдо, виногради, њиве и шума на брду према Малом Градишту (С); ЖУТ: Жуто брдо: потез у центру села (C); Чесма на жуто брдо, спомен чесма (С); КУС: Куси до, њива (С); МАЛИ: Мали Диван, обрадива земља (К); Мали Облеж, обрадива земља (К); ПАРЛОГ: Парлозе, обрадива земља (С); ПЕСАК: Пескови, потез на крају села на ком су постојали мајдани за вађење песка потребног за израду бибер црепа (C); СМОНИЦА: Смонице, њиве (C);

г) Метафорски називи

ГЛАВА: Главица, обрадива земља (C); ГРНЕ: Грнчар, шума и утрина (C); Грнчаревац, извор (C); Грнчић, део сеоског насеља (С); ДИВАН: Диван, брдска греда која се протеже до атара села Кобиља; Велики Диван, део потеза Диван; Мали Диван, део потеза Диван (С,К); КРОВ: Кров, њива (К); НОГА: Стрчинога/Штрчи нога, шума (C); ТАВАН: Таванчић, обрадива земља поред сеоског насеља (С); КРАК: Црчини кракови, њиве према Дубоком потоку које имају облик њудских удова $(\mathrm{C}) .{ }^{10}$

д) Фитоними

БРЕСТ: Шес бреста, њива на крају села према Салаковцу (С); ГРАБ: Грабовач, равница, обрадива земља (С); КРУШКА: Крушар, њиве (С); ЛИПА: Липовача, обрадива земља на брду према Забреги (С); РЕПУХ: $P e-$ пушина, њива (С); ЦЕР: Церак, шумски потез на крају села према Гареву (С); Церовац, њиве у Стигу (С).

\footnotetext{
${ }^{10}$ На влашком језику краку значи нога. И у српским говорима северне Метохије краци су ноге у пејоративном значењу. Кад неко умре или уради нешто неприкладно, неморално, погрдно се каже да је Отегао краิце.
} 


\section{ђ) Зооними}

3MAJ: 3мајеваи, потез на ком се налази археолошки локалитет из бронзаног доба. ${ }^{11}$ На Змајевцу су одржавани сабори на Велику Госпојину и на Крстовдан (С); ЗМИЈА: Змињак, потез на којем има змија (С); КОБИЛА: Кобиљски пут, сеоски асфалтни пут од Кобиља до Кучевачког пута, асфалтиран 1989; Старо Кобиље, селиште на ком се некада налазило село, у делу села према Забрђу; КОЗА: Козје шуме, њиве у делу села према Љубињу (C); МЕЧКА: Мечкин гај, потез у ком се налазе приватни забрани и државна шума (К); ПЕТАО: Петловаи, тако се назива јужни део сеоског насеља, данашња улица Максима Горког (С); ТОВАР: Товарија, потез и поток који се назива још и Дрмски поток. Настаје од Шеретског и Јерничког потока.

е) Културни топоними

БАЧИЈА: Бачије, пашњак (С); БРАНИК: Шуиики брник, шума на крају села према Малом Градишту (C); ВИНОГРАД: Виногради, њиве и шумарци (С); Виноградско брдо, Кьмпу маре (К); Балу вињилор, тако се на влашком језику назива потез Паљушевац (К); ЗАБЕО: Забела, потез, обрадива земља (С); КУЋА: Кућиште, старо селиште рода Берјанци који су основали село Смољинац (C); МЕЂА: Међа, потез на крају села према Малом Градишту (C) ; ПОЈИЛО: Појено, њива и шума у потезу на којем има више извора; Појеิь, в. Појено; ПОљЕ: Пољана, њиве и извор Под гајем; ПУТ: Божевачки пут, макадамски пут за суседно село Божевац (К); Кобиљски пут, сеоски асфалтни пут од Кобиља до Кучевачког пута, асфалтиран 1989. (К); Куљански пут, локални пут од села према суседној Кули даље према Петровачкој магистрали, асфалтиран 1978. (К); Кучевачки пут, регионални пут од Пожаревца за Кучево (К); Пут за Аљудово, макадамски тракторски пут преко брда Зебац за Аљудово (К); Пут за Дугарнииу, сеоски пут за суседна села Раброво и Мустапић (К); Пут за Забрђе, неасфалтирани пут за део села у ком је некада одржаван сабор у мају кад се брало биље (К); Пут за Јернииу, један од сеоских сокака (К); Пут за Манастирииу, насипан макадамски пут за суседна села Манастирицу и Аљудово (К); Пут за Старичину, сеоски тракторски пут (К); КОП: Прокоп, шума источно од села (С); СЕЛО: $\mathrm{Ce}$ лиште, обрадива земља више села (С, К); Селишћор, ьива (К); СПОМЕНИК: Рођин спомен, место на ком је подигнуто спомен обележје народном хероју Драгославу Дражи Марковићу Рођи (С); ТОР: Торови, борова шума источно од центра села (С); Ториште, в. Торови (С), ЦАРИНА: Царине, њиве са ограђеним пашњаком за стоку (C); ШТАЛА: Штале, простор на ком су некада биле задружне штале (C).

\footnotetext{
${ }^{11}$ Сачувана је легенда о томе како је ово место добило име. У селу говоре да дунавски шаран када напуни четрдесет година израња из Дунава и око поноћи, када је млад месец, узлеће и постаје златан. Долеће до извора у селу Смољинцу, остављајући златан траг од крљушти на небу, трансформише се у змаја и ноћу обљубљује младе сеоске жене, а дању се скрива по шупљем дрвећу. Жене које су биле змајеве љубавнице умирале су младе.
} 
ж) Сакрални објекти

ГРОБ: Ивков гроб, потез у Дубоком потоку; Томин гроб, обрадива земља, шума и пашњаци на брду Дивану према суседном селу Забреги; ГРОБљЕ: Берјанско гробље, старо гробље на селишту Кућиште (С); Горње гробље, једно од два сеоска гробља на брду више села према Малом Градишту (C); Доње гробље, сеоско гробље на почетку села, поред магистралног пута за Кучево. Занимљиво је и то да је на гробљима у Смољинцу, над скоро сваким спомеником озидана спомен кућица, па гробља изгледају као нека мала села у селу (C); Јерничко гробље, старо гробље из времена Римљана. На том месту се налази археолошко налазиште на ком су нађени предмети из времена владавине Римљана (К); КРСТ: Kpcm, предео у потезу Парлози на крају села према Касидолу (C); Код крста, молитвиште у потезу Парлози (C).

У ову групу смо сврстали и три топонима о којима мештани говоре да именују свето место: Старичина, на том месту направљена је капелица Миливоја Мијајловића. У народу постоји предање да је Старичина била велико село у време када су се само мушкарци удавали, а жене остајале у својим кућама и биле господари породица. Људи су порекло рачунали само по мајци па се тако село смањивало све док у њему није остала само једна старица после чије смрти је село изумрло, али му је по тој старици из матерјархата остало име (К); Стричина, в. Старичина (К); Пут за Старичину, сеоски тракторски пут (К); Старичински пуm, једна од саставница потока Строш (K).

\section{II. Топонимија антропонимског порекла}

a) Једночлани називи

Берјанци (С), Голашоњ (К), Домињащчи (C), Караџинц̧и (C), Матанцฺи (C), Негрићи (C), Црчићи (C), Бишоњ (К), Рофоњ (К).

б) Двочлани називи

Антонијевића воденица (К), Букалова бачија (С), Ваља Николоњ (К), Васића воденица (К), Влајин кладенач (C), Вукин до (C), Живкова воденица $(\mathrm{K})$, Ивков гроб (C), Икин церјак (C), Коста маре (К), Крајића воденица $(\mathrm{K})$, Леличин поток (K), Љубомирова стругара $(\mathrm{C})$, Марин поток (K), Павлов кладенач (C), Пешин рам (C), Рођин спомен (C), Стеванова чесма (C), Стошине воде (C), Стриине воде (C), Титина улица (C), Томин гроб (C), Црчини кракови (C), Шуицки брник (C). 


\section{Iii. Творбена анализа}

У топонимији проучаваних села регистрована су 102 једночлана микро назива међу којима има и неизведених онима: $\operatorname{Amap}(\mathrm{C})$, Баре $(\mathrm{C}, \mathrm{K})$, Бачије (C), Баруга (C), Бишоњ (К), Бучура (C), Гај (C), Диван (C, К), Дероње (C), Кључ (C), Кров (К), Крст (C), Лак (К), Локва (C), Међа (C), Облеж (К), Парлозе (C) Пљьошта (C), Река (C), Рит (C), Стиг (C), Черет (К), Честа (C), Чукур (C), Шерет (К), Штале (C).

a) Топономастичке изведенице

Једночлани топоними настали деривацијом додавањем именичких форманата деминутивног, аугментативног и месног значења.

-ак/јак: Змињак (С), Точак (С), Церак (C), Шибак (C), Мељак (К)

-ана: Пољана (C)

-ар: Грнчар (C), Дубрар (К), Крушар (C),

-ац: Берјании (C), Глибоваи (C), Грнчареваи (C), Зебаи (К), Змајеви (C), Караиинци (С), Матанции (С), Петловаи (С), Ранковаи (С), Стублинаи (С, К), Студенаи (К), Церовач (C),

-ача: Вртаче (C), Липовача (C),

-ија: Товарија (К)

-ина: Падин (К), Репушина (С), Старичина (К), Стричина (К), Ступин (К), Царина (К), Царине (C),

-ић: Грнчић (C), Негрићи (C), Таванчић (C), Црчићи (C),

-ица: Водиие (К), Главица (C), Деонице (С), Дугарнице (К), Јернице (К), Смонице (С), Средииа (C), Шумиие (C),

-иште: Бежаниште (С), Косиште (K), Kућиште (C), Падалиште (C), Селиште (C, K), Tориште (C),

-je: Забрђе $(\mathrm{K})$.

\section{б) Двочлани топоними}

Међу двочланим топонимима апелативног порекла налази се двадесет три примера. Већина двочланих конструкција је забележена у српском селу Смољинцу, а осам потврда бележимо у влашком селу Кобиљу. Најчешће су то синтагме типа придевски атрибут + апелатив: Бабин кладенаи, Беле воде, Бели поток, Голо брдо, Велики Стиг, Мали Стиг, Горња река, Горње гробље, Доња река Доње гробље, Дубоки поток, Козје шуме, Куси до, Старо брдо, Шарена вода (С); Велики Диван, Мали Диван, Велики извор, Велико поље, Велики Облеж, Мали Облеж, Мечкин гај (К). У Кобиљу је записан и топоним са присвојном заменицом у одредбеном делу синтагме Наша вода. 
в) Трочлани и четворочлани топоними

Драге Савином юива (C), Извор у Раниковиу (C), Чаир над село (C); Код Рофоња бунар (К), Поток од чесме (К), Пут за Аљудово (К), Пут за Дугарнииу (К), Пут за Забрђе (К), Пут за Јернииу (К), Пут за Манастирииу (К), Пут за Старичину (К), Чесма код Недељковића (К).

У атару Смољинца регистрована су два четворочлана хидронима: Извор код Свете Петке (C), Чесма на жуто брдо (C); у атару Кобиља нема четворочланих топонима.

г) Топономастичке сложенице

У нашој грађи налази се девет топономастичких сложеница различитих структура. Већина њих има структуру префикс + именица или глагол, а топоними Виногради, Содо и Стрчинога и у првом и у другом делу сложенице имају пунозначне лексеме, именску реч или глагол (Јашовић 2018 , 32-33).

Виногради (C), Подливада (C), Домињащуи (C), Прода (C), Прокоп (C), Островач (С), Содо (Суви до) (С), Стрчинога (С); Забрђе (К).

Класификована топонимија пописана у српском селу Смољинцу и у влашком селу Кобиљу је српска односно словенска. Ипак у селу Кобиљу грађа је записана у разговорима вођеним са мештанима влашког порекла који су билингви и свакодневно се служе својим матерњим влашким говором и српским језиком на којем се и школују.

Ипак, од укупно пописана 84 топонима који се користе за именовање реалија у катастарској општини Кобиље тринаест топонима чули смо и на влашком говору. Неки од њих користе се само на влашком и могу бити апелативног Лак (језеро, језерие), Стру ои, Черет ${ }^{9}$ и чешће антропонимског порекла: Бишою, Голашою, Рофою.

Већину двочланих назива информатори су нам казивали на влашком и исти називи превпдили на српски језик: Ваља Николою-Николајевића долина, Огашу виюилор-Виноградски поток, Кьлпу маре-Велико поље, Ђалу виюилор-Дуги виногради; али се ова реалија именује и онимом Паљушевац.

Неки топоними су просто повлашени српски географски називи: Падин, Појењ, Селишћор, Код Рофоњ а бунар. ${ }^{12}$

\footnotetext{
${ }^{12}$ Поређења ради навешћемо податак да је у селу Аљудову које се са једне стране граничи са влашким селом Кобиљем и са друге стране, такође, са влашким селом Манастирицом пописано је десетак влашких топонима: Огашу виғилор, Огашу лу лупу, Огашу Kоста, Праури, Фьнтен лу Гаља, Фьнтен лу Лоја (Јашовић и Јовановић, )
} 


\section{IV. Регистар топонима}

a) Смољинац

Ајдучки кла"денац, из ${ }^{13}$

Ӓтар, њ

Ба'бин кла"денац, из

Барpe, њ

Бачйје, паш

Бежӓниште, сел

Беиле вӧде, из

Бели по"ток, п

Берја”нско гробље, г

Берја́нци, зас

Бу”калова бачйја, ш, паш

Буруига, п

Бучу๊ра, из

Вёлики Стию, по

Виногра'ди, њ, ш

Вла̄јиิн кла"денац, из

Вӯкиин дог, д

Вртӓче, њ, ш

Гај], ш

Главйца, њ, л, паш

Голло бр"до, њ, ш

Горрња рекка, $\mathrm{p}$

Горње гробље, г

Гра“бовац, њ

Грнчар, ш

Грнча̄реввац, из, ш

Грнчић, зас

Гр"чка ма́ла, зас

Гр"чка ӱлица, зас

Деонйце, њ

Дера"ње, њ

Диваิн, њ, л, паш

Доло́ви, њ

Домиња́ци, њ

13 Уз топониме у овом Регистру користили смо се скраћеницама:б-бунар, в-воденица, г-гробље, д-до, з-запис, зас-заселак, изизвор, j-језеро/језерце, њ-њива, п-поток, паш-пашњак, по-поток, пу-пут, р-река, селселиште, чес-чесма.
Доюња рекка, p

Доње гробље, г

Дра̄ге́ Са̄ви"ном њйва, њ

Дубо"ки пӧток, п

Жуто бр"до, њ, л

Забела, њ

Змајјевац, ш, л, паш

Змйња̂к, л, паш

Ивков гро'б, г

Ӥзвор код Свете Петке, из

Ӥзвор у Ранико́вцу, из

Йкиิн цёрјак, ш

Јазови/Ја̄зовви, л

Караџинци, зас

Кључ, њ

Код кр"ста, 3

Коззје шу"ме, њ

Кр"ст, 3

Крушарр, њ

Кусси доि, д

Кӳћиште, сел

Ла"вице, њ, л

Ла̄вни"чке вравтнице, њ, л

Лйповача, њ

Ло"ква, њ

Љубо"мирова стругӓра, ш

Маิли Стиг, њ, л

Матаิнци, зас

Méђа, њ

Моравска, зас

Над сёло, њ

Не̄гри́ћи, зас

Островвац, л

Паивлов кла"денац, из

Палдалиште, њ

Парлоз́е, њ

Пе̄ско'ви, паш

Пе̄тло'вац, зас

Пе̄шиิн рӓм, ш, л 
Пљоі́шта, њ

Пољӓна, из, њ

По̆пов бунар, из

Предли"вада, л

Према Шапине, њ, л

Продда, њ, паш

Про́коп, ш

Ранйковац, из, л

Река, $\mathrm{p}$

Репӱшина, њ

Рйт, њ

Ро̄ђин спӧмен, паш

Сёлиште, њ

Смо̄нйце, њ

Со̄до, њ

Средйца, њ

Старо бр"до, њ, л

Стёванова че"сма, чес

Стиг њ, л

Стӧшине вӧде, из

Стршшине вӧде, из

Стр"чинога, ш

Стубли́нац, из

Тавӓнчић, њ

Тйтӥна ӱлица, зас

То̄мин гробб, паш

Торровви, ш

Торриште, ш

Тӧчак, из

У Касидоллско, њ

У Ре̄ке́, $\mathrm{p}$

Царрине, њ

Церак,, њ

Црчиини кра̋кови, њ

Црчиићи, њ, л

Чаирр над сёло, њ

Чесма на Жуто бр"до, чес

Че"ста, њ

Чу้кур, паш

Шапинско пољље, ш, паш, л

Шарёна вӧда, из

Шес бре́ста, њ
Шибаิк, паш

Шталле, њ, паш

Штр"чи нӧга, ш

Шӯйцки брникк, ш

Шӳмице, ш

б) КОБИљЕ

Антонйјевића воденйца, в

Бӓре, њ, л

Бишоิњ, из

Божевачки пут, пу

Бӱгарска ма́ла, зас

Васића воденйца, в

Вёлики Диваิн, њ, л, паш

Вёлики Ӧблеж, л, њ, паш

Ваิља Николоњ, њ, л

Вёлики йзвор, из

Вёлико пӧље, њ, л

Виногрӓдско бр"до, њ

Вӧдице, из, паш

Водиицки по"ток, п

Голашоњ, чес

Диваิн, њ, л, паш

Драгомйро"вића и"звор, из

Дубравииш`а, њ

Дубраิ, њ

Дуга̄рнйце, њ

Дугарнички по"ток, п

Ђӑлу вињилор, њ, л

Живкова воденйца, в

За̄бр’ђе, њ, л

Зёбац, ш, њ

Је̄рнйца/Је̄рнйце, ш

Јеррнйчки пӧток, п

Је̄рни"чко гроббље, г

Кӓсиште, њ

Кь"мпу маре, њ

Кобиิљски пут, б

Ко"ста маре, њ, л

Крајића водениица, в

Кров, њ

Кулсско по̆ље, њ, л 
Куљӓнски пут,, пу

Кӱчевачки пут, пу

Лӓк, j

Лёличин пӧток, п

Маิли Диваิн, њ, л, паш

Маิли Оิблеж, њ, л, паш

Ма́риин пӧток, п

Мељак, њ, л

Мељаิчка доли"на, њ, л

Мељаิчки по̆ток, п

Мёчкин гај], ш

Милоса"вљевића водениица, в

Нӓша чёсма, чес

Ӧблеж, њ, л, паш

Огашу вињилор, њ, л

Падиін, ь

Паљӯшёвац, њ

Перииш, њ, л

Петриіш, ш, њ

Подине, њ

Поојено, њ, ш

Појёњ, њ, ш

Пӧток од чёсме, п

Путт за Аљўдово, пу
Пут за Дугарницу, пу

Пут за Забрђе, пу

Пут за Јерницу, пу

Пут за Манасти"рицу, пу

Пут за Старйчину, пу

Рофоњњ, 6

Сёлиште, њ, л

Селишћор, њ

Спомен-чесма, чес

Стари"чина, њ, л, ш

Старӥчински пӧток, п

Старо Кобиิље, сел

Стриичина, сел

Струӧш/Стру оิш, п, њ, л

Стӱденац, из

Ступин, њ

Товарйjа, њ, л

Черрет, њ, ш

Царрина, њ

Царрински по"ток, п

Цигӓнска че"сма, чес

Цйгански пӧток, п

Че"сма код Недељљковића, чес

Шёрет, њ, ш

\section{Литература}

Антонијевић, М. (2004). Милић Мића Антонијевић, Долина Витовнице, географско-историјска монографија, Народни музеј Пожаревац, Пожаревац.

Јашовић Г. (2016). Голуб Јашовић, Српска и албанска топонимија села Ослара код Бујановиа, Зборник радова Филозофског факултета Универзитета у Приштини, књига XLVI/2, Косовска Митровица, стр. 429-444.

Јашовић Г. (2011). Голуб Јашовић, Топонимија села Угљара код Приштине, Зборник радова Филозофског факултета у Приштини, књига XL, Филозофски факултет Универзитета у Приштини, Косовска Митровица, стр. 13-24.

Јашовић, Г. (2017). Голуб Јашовић, Прилог проучавању ономастике села Ћушка код Пећи, у: Даница Радуновић Столић (ур.), зборник радова са 12. конференције „Васпитач у 21. веку, Рефлексије савременог доба на васпитно - образовни рад у предшколској установи, књига 16, 2017, Алексинац: 278-285.

Јашовић, Г. (2018). Голуб Јашовић, Лични и породични надимии села Смољиниа, Стиг, часопис за књижевност, уметност и културу, број 124, Центар за културу, Мало Црниће, стр. 88-98. 
Јашовић Г. (2018). Голуб Јашовић, (коаутор Славица Јовановић), Ономастика села Мало Црниће у Стигу, Стиг, часопис за књижевност, уметност и културу, број 121, Центар за културу, Мало Црниће, стр. 89-93.

Јашовић Г. (2018). Голуб Јашовић (коаутор Славица Јовановић), Микротопонимија села Кобиља, Стиг, часопис за књижевност, уметност и културу, број 120, Мало Црниће, стр. 81-84.

Јашовић Г. (2018). Голуб Јашовић, (коаутор Славица Јовановић), Антропонимија и топонимија села Крављи До, Стиг, часопис за књижевност, уметност и културу, Мало Црниће, број 123, стр. 86-93.

Јашовић Г. (2018). Голуб Јашовић, зборник, Историјски архив Крушевац, Удружење за културу и уметност „Логос“, Крушевац-Својново.

Klaić, B. (1968), Bratoljub Klaić, Veliki rječnik stranih riječi, izraza i kratica, „Zora“, Zagreb.

Младеновић, Б. и Јацановић Д. 2002. Бен Младеновић и Драган Јацановић, Haсеља Браничева, географско-археолошко-историјска монографија, НИГП „Радојковић“ и COTOS, Пожаревац.

Golub M. Jašović

\section{TOPONYMS RECORDED IN SERBIAN VILLAGES SMOLJINAC AND VLACH VILLAGE KOBILJE IN SOUTHERN STIG NEAR POŽAREVAC}

\section{Summary}

This paper deals with toponyms recorded in a part of Braničevo area, in villages that are part of the south Stig area near Požarevac. These villages are located on the eastern border of Serbia and Romania. We have chosen village Smoljinac, whose residents are of Serbian nationality and village, Kobilje, whose residents have Vlach origins. Both villages are located in valleys. Village Kobilje is situated on the sides of Homolje Mountains. However, we have managed to record a significant amount of toponyms, around hundred toponyms per village. We have also conducted semantical and morphological analyses of toponyms, classified them and made a list of collected onyms.

Key words: Southern Stig, Homolje, Smoljinac, Kobilje, antroponymy, toponymy. 